\title{
Depth and water mass zonation and species associations of cold-water octocoral and stony coral communities in the southwestern Atlantic
}

\author{
R. C. M. Arantes ${ }^{1,2}$, C. B. Castro ${ }^{1, *}$, D. O. Pires ${ }^{1}$, J. C. S. Seoane ${ }^{2}$ \\ ${ }^{1}$ Museu Nacional, Universidade Federal do Rio de Janeiro (UFRJ), Quinta da Boa Vista, s/n, São Cristóvão, Rio de Janeiro, \\ 20940-040, Brazil \\ ${ }^{2}$ Departamento de Geologia, UFRJ, Av. Athos da Silveira Ramos, 274, Bloco G, Cidade Universitária, Rio de Janeiro, \\ 21941-916, Brazil
}

\begin{abstract}
The Southwest Atlantic continental margin between latitudes 21 and $23^{\circ} \mathrm{S}$ comprises the Campos Basin area. Its continental shelf is some $100 \mathrm{~km}$ wide, with the slope starting between 80 and $130 \mathrm{~m}$ in depth. The slope is about $40 \mathrm{~km}$ wide, extending deeper to the south $(2000 \mathrm{~m})$ than to the north $(1500 \mathrm{~m})$. Water masses influencing the area include (1) surficial tropical water (TW), 250 to $300 \mathrm{~m}$ depth; (2) South Atlantic central water (SACW), below TW 300 to 550 m; (3) Antarctic intermediate water (AIW), between 550 and $1200 \mathrm{~m}$ depth; and (4) North Atlantic deep water (NADW), 1200 to $3500 \mathrm{~m}$ depth. Distributions of octocorals (25 genera, 32 species/morphotypes) and stony corals $(27,11)$ and associations among taxa and with water masses were analyzed. Different communities were found over 3 depth ranges. Complete dissimilarity was observed between the continental shelf margin/upper slope and the middle-lower slope. The shallower depth range (52 to $760 \mathrm{~m}$ ) was influenced by TW, SACW and the upper limit of AIW, while 11 species/morphotypes occurred exclusively in the middle depths (1000 to $1200 \mathrm{~m}$ ), under the sole influence of AIW. No species were exclusive to the deepest depth range (1200 to $1605 \mathrm{~m})$, which is bathed by NADW. Middle slope areas were distinct from one another, while lower slope areas were more homogeneous. Co-occurrences of species indicate the type of environment they live in, as soft or hard bottoms. One group of species indicative of cold-water coral communities includes Lophelia pertusa, Enallopsammia spp., Corallium niobe and Paragorgia johnsonii.
\end{abstract}

KEY WORDS: Deep sea $\cdot$ Octocorallia $\cdot$ Scleractinia $\cdot$ Depth $\cdot$ Water masses $\cdot$ Zonation

\section{INTRODUCTION}

Deep-water octocorals of the South Atlantic are currently poorly known, with little work published (Medeiros \& Castro 1999, Castro \& Medeiros 2001, Arantes \& Medeiros 2006, Castro et al. 2006), chiefly due to the difficulties and costs of sampling. Exploration in such extreme depths is much more complex than in shallower waters and demands greater operational and logistical infrastructure. Two important deep-water reefs in southeastern Brazil are located in the Campos and Santos Basins (Viana et al. 1998, Sumida et al. 2004, Castro et al. 2006), which host significant hydrocarbon exploration and production.
Campos Basin lies along the southwestern margin of the South Atlantic Ocean, on the Brazilian continental margin between 21 and $23^{\circ} \mathrm{S}$ (offshore the cities of Vitória and Cabo Frio, in the states of Espírito Santo and Rio de Janeiro, respectively). It occupies a total area of over $100000 \mathrm{~km}^{2}$. The shelf averages $100 \mathrm{~km}$ in width and the slope begins in 80 to $130 \mathrm{~m}$ water depth at the northern and southern limits, respectively. The slope spans over $40 \mathrm{~km}$ at an average gradient of $2.5^{\circ}$. Its base is shallower to the north $(1500 \mathrm{~m})$ and deeper to the south (2000 m) (Viana et al. 1998; see Fig. 1).

Four major water masses influence the Campos Basin (Viana et al. 1998; see Table 1): tropical water (TW, in the upper shelf), South Atlantic central water (SACW, 
in the outer shelf and part of the upper slope), Antarctic intermediate water (AIW, which bathes the rest of the upper and middle slopes) and North Atlantic deep water (NADW, which influences the lower slope of the Campos Basin). Water masses seem to have a significant influence on the distribution and composition of megafaunal communities (Levin \& Godday 2003).

Comprehensive knowledge of the distribution of deep-water taxa is significant to deep-water conservation issues (Watling \& Auster 2005). Understanding the influence of water masses on corals may help estimate their distribution, dispersal, and area connectivity. In the present study, Octocorallia and Scleractinia (Cnidaria: Anthozoa) from the outer continental shelf and slope from the Campos Basin, from stations under the influence of different water masses were evaluated as to their spatial distribution and association of species.

\section{MATERIALS AND METHODS}

Two major projects contributed the sample data used in our analyses: Assessment of the Sustainable Yield of the Living Resources in the Exclusive Economic Zone (REVIZEE; Castro et al. 2006), coordinated by the Inter-Ministry Marine Resources Commission (CIRM), and the Campos Basin Deep-sea Environmental Project (OceanProf campaigns I and II), coordinated by Petrobras. Samples obtained by bottom trawling were preliminarily identified using Bayer (1981), Williams (1995) and Cairns (1979, 2000), with added literature used to reach the rank of species. Specimens were deposited in the Cnidaria collection at the Museu Nacional, Rio de Janiero (MNRJ).

Samples spanned 49 stations, all distributed within 1 degree of latitude, with 41 from the OceanProf I and II cruises (Octocorallia and Scleractinia), and 8 from REVIZEE (Octocorallia only). Several stations retrieved a single species, and some stations were sampled by both OceanProf campaigns. Due to these characteristics, for analytical purposes, stations were grouped (Table 1), and the overall area was subdivided based on 2 criteria described by Viana et al. (1998). The first criterion pertained to the vertical stratification of water masses: (1) continental shelf and upper slope, which are influenced by SACW and upper AIW; (2) medium slope, influenced by AIW; and (3) lower slope, influenced by NADW. The second criterion was geomorphological, and corresponded to subdivision of areas according to the occurrence of canyons and differences in declivity. These criteria subdivided the Campos Basin into 13 areas (Fig. 1, Table 1).

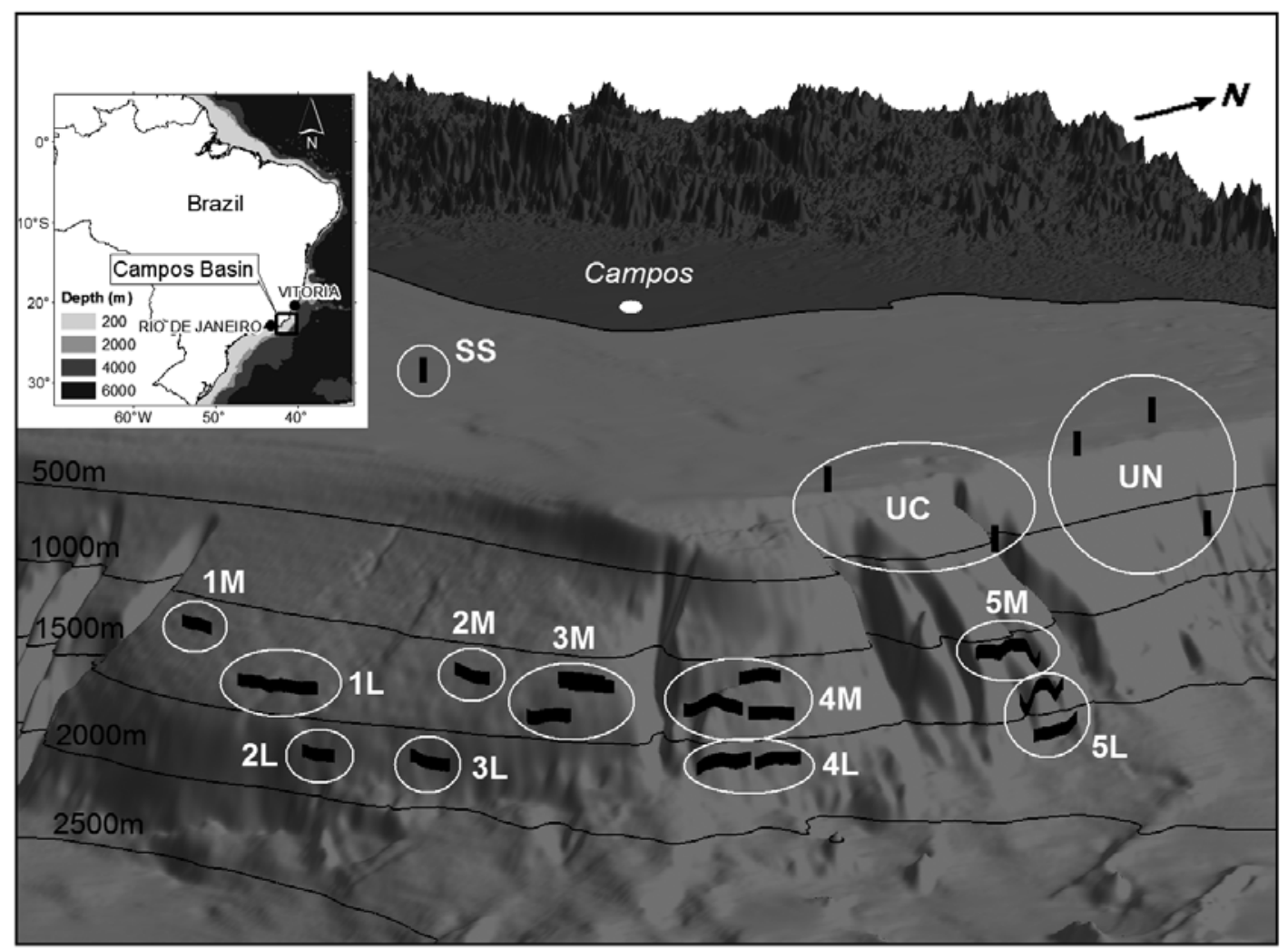

Fig. 1. Location and 3-D model of Campos Basin bathymetry, prepared from publicly available data (www.bdep.gov.br), highlighting geomorphology and area subdivision. Vertical exaggeration: $15 \times$ bathymetry, $7.5 \times$ topography. SS: shelf (south); UC: upper slope (central); UN: upper slope (north); IM to 5L: areas 1 to 5 middle/lower slope 
Table 1. Campos Basin subdivision in areas of similar geomorphology and water mass influence: name and code of the areas and number of stations in each area. AIW: Antarctic intermediate water; NADW: North Atlantic deep water

\begin{tabular}{|lccc|}
\hline Area & Code & No. of stations & Depth range (m) \\
\hline Shelf (South) & SS & 1 & 60 \\
Upper slope (North) & UN & 4 & $50-775$ \\
Upper slope (Central) & UC & 3 & $90-575$ \\
Area 1 middle slope (AIW) & 1M & 2 & $1145-1160$ \\
Area 1 lower slope (NADW) & 1L & 6 & $1355-1390$ \\
Area 2 middle slope (AIW) & 2M & 2 & $1160-1210$ \\
Area 2 lower slope (NADW) & 2L & 2 & $1755-1785$ \\
Area 3 middle slope (AIW) & 3M & 2 & $1145-1420$ \\
Area 3 lower slope (NADW) & 3L & 4 & $1705-1780$ \\
Area 4 middle slope (AIW) & 4M & 4 & $1135-1380$ \\
Area 4 lower slope (NADW) & 4L & 12 & $1655-1720$ \\
Area 5 middle slope (AIW) & 5M & 3 & $1080-1275$ \\
Area 5 lower slope (NADW) & 5L & 4 & $1335-1680$ \\
\hline
\end{tabular}

\section{Cluster analysis and MDS}

The first Q-mode cluster analysis dendrogram and MDS (Fig. 2) for Octocorallia only clearly indicate 3 distinct areas: shelf, upper slope and middle and lower slope. The dissimilarity between shelf and slope areas was $100 \%$ (SIMPER).

Q-mode cluster analysis delineates 3 main groups in the middle and lower slope areas. These include one central and one northern Campos Basin middle slope area, with low similarities $(<40 \%)$, as well as a third group comprising the lower slope and an area from the middle slope in the southern part of the basin, with a similarity

Two distinct aspects were considered in the evaluation of the Octocorallia fauna. First, the Octocorallia fauna of the shelf, upper slope (subdivided into 3 areas), middle and lower slopes (each subdivided into 5 areas) were compared. Next, the distributions of Octocorallia and Scleractinia fauna were compared (as the latter are the main deep reef-forming taxa), using data from the middle and lower slopes only. This approach was determined by the absence of samples of Scleractinia in shallower stations and the completely distinct fauna among shallow and deep stations.

Areas with similar community structure (Q-mode) and species co-occurrence across sites (R-mode) were determined using cluster analysis and multi-dimensional scaling (MDS) based on presence/absence of species/morphotypes. Average group similarity and differentiation among groups was determined using similarity percentage (SIMPER) analysis. Similarity matrices were calculated using the Bray-Curtis coefficient in PRIMER 4.0 (Clarke \& Warwick 1994). The cutting line for each dendrogram is based on comparison with the respective MDS grouping as well as the length between consecutive branches.

\section{RESULTS}

\section{Matrix}

The Octocorallia fauna in the Campos Basin comprises 25 genera and 32 species or morphotypes (Table 2). Morphotypes, which represent unnamed or unidentified species, are treated as distinct species in the analysis and discussion. A matrix of species occurrence in the pre-defined areas was used in the analyses (Table 2). index $>40 \%$ (Figs. $1 \& 2$ ). Analyses indicate that middle shelf areas are more dissimilar from each other, whereas lower shelf areas are grouped more closely together (Figs. 2 \& 3).

Two groups of areas indicated in Fig. 2 exhibit high within-group similarities due to distributions of only 4 octocoral species. Group A (Area 1M, 5L; $80 \%$ average similarity) comprises Anthomastus grandiflorus and Anthoptilum murrayi, each contributing 50\%, while
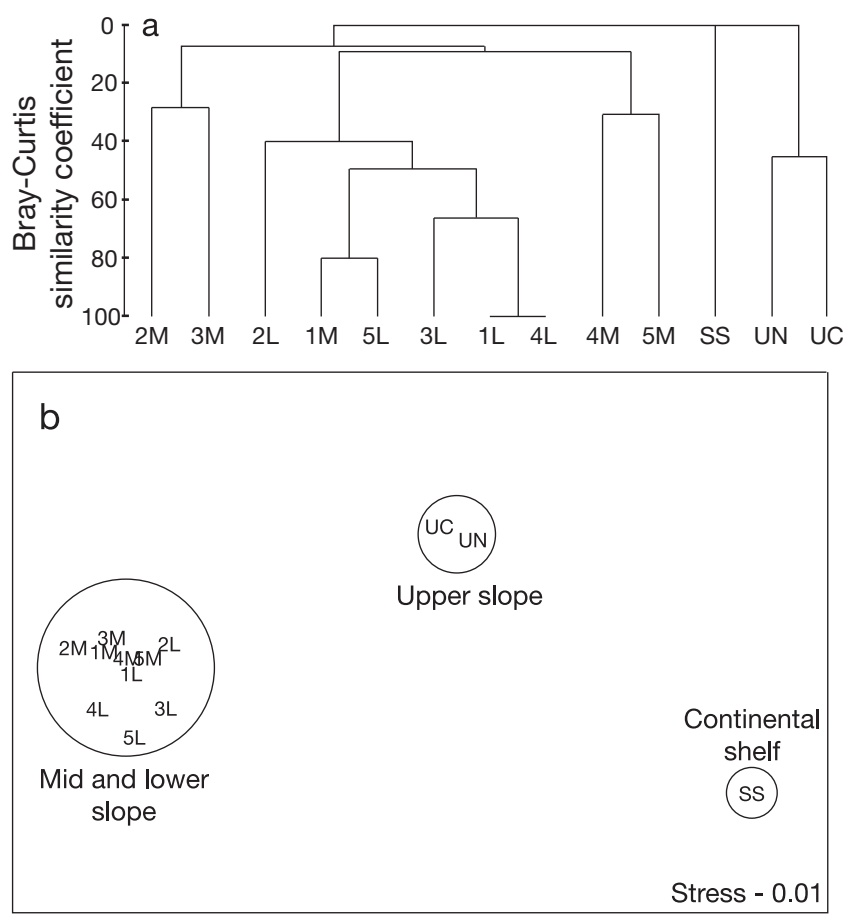

Fig. 2. (a) Cluster analysis dendrogram and (b) multidimensional scaling (MDS) ordination of sites in the shelf and slope areas (see Fig. 1 for area location and subdivision, Table 1 for area codes), based on occurrence of Octocorallia 
Table 2. Presence/absence matrix of Octocorallia and Scleractinia occurring on the shelf and slope of the Campos Basin, with respective depths. Area codes as in Table 1. X: presence

\begin{tabular}{|c|c|c|c|c|c|c|c|c|c|c|c|c|c|c|c|}
\hline & \multirow{2}{*}{ Species code } & \multirow[b]{2}{*}{ SS } & \multirow[b]{2}{*}{ UN } & \multirow[b]{2}{*}{$\mathrm{UC}$} & \multirow[b]{2}{*}{$1 \mathrm{M}$} & \multirow[b]{2}{*}{$1 \mathrm{~L}$} & \multicolumn{2}{|c|}{ - Area code } & \multirow{2}{*}{$3 \mathrm{M}$} & \multirow[b]{2}{*}{$3 \mathrm{~L}$} & \multirow[b]{2}{*}{$4 \mathrm{M}$} & \multirow[b]{2}{*}{$4 \mathrm{~L}$} & \multirow[b]{2}{*}{$5 \mathrm{M}$} & \multirow[b]{2}{*}{$5 \mathrm{~L}$} & \multirow{2}{*}{ Depth $(\mathrm{m})$} \\
\hline & & & & & & & $2 \mathrm{M}$ & $2 \mathrm{~L}$ & & & & & & & \\
\hline & Octocorallia & & & & & & & & & & & & & & \\
\hline 1 & Acanella arbuscula & & $\mathrm{X}$ & $\mathrm{X}$ & & & & & & & & & & & $579-766$ \\
\hline 2 & Acanella sp. & & & & $\mathrm{X}$ & & & & & & $\mathrm{X}$ & & $\mathrm{X}$ & & $1082-1114$ \\
\hline 3 & Anthomastus grandiflorus & & & & $\mathrm{X}$ & & $\mathrm{X}$ & & & & & & & $\mathrm{X}$ & $1082-1577$ \\
\hline 4 & Anthoptilum murrayi & & & & $\mathrm{X}$ & $\mathrm{X}$ & & $\mathrm{X}$ & & $\mathrm{X}$ & & $\mathrm{X}$ & & $\mathrm{X}$ & $1059-1114$ \\
\hline 5 & Anthothela grandiflora & & & & & & & & & & $\mathrm{X}$ & & & & 1114-1605 \\
\hline 6 & Anthomastus sp. & & & & & & & & & & $\mathrm{X}$ & & $\mathrm{X}$ & & 1110 \\
\hline 7 & Bebryce cinerea & & $\mathrm{X}$ & & & & & & & & & & & & $240-300$ \\
\hline 8 & Bebryce sp. & & $\mathrm{X}$ & & & & & & & & & & & & $60-180$ \\
\hline 9 & Calyptrophora pillsburyae & & & & & & $\mathrm{X}$ & & $\mathrm{X}$ & & & & & & $1140-1152$ \\
\hline 10 & Candidella imbricata & & & & & & & $\mathrm{X}$ & & & $\mathrm{X}$ & & & & 1110-1605 \\
\hline 11 & Corallium niobe & & & & & & & & $\mathrm{X}$ & & & & & & $1127-1152$ \\
\hline 12 & Ellisella elongata & $\mathrm{X}$ & $\mathrm{X}$ & & & & & & & & & & & & 100 \\
\hline 13 & Leptogorgia setacea & & & $\mathrm{X}$ & & & & & & & & & & & $43-60$ \\
\hline 14 & Leptogorgia violacea & & & $\mathrm{X}$ & & & & & & & & & & & 82 \\
\hline 15 & Leptogorgia sp. & & $\mathrm{X}$ & & & & & & & & & & & & 180 \\
\hline 16 & Muriceopsis sp. & & $\mathrm{X}$ & $\mathrm{X}$ & & & & & & & & & & & $52-100$ \\
\hline 17 & Narella alvinae & & & & & & & $\mathrm{X}$ & & & $\mathrm{X}$ & & & & 1110-1605 \\
\hline 18 & Nicella sp. ${ }^{a}$ & $\mathrm{X}$ & & $\mathrm{X}$ & & & & & & & & & & & $110-500$ \\
\hline 19 & Nidalia sp. & & $\mathrm{X}$ & $\mathrm{X}$ & & & & & & & & & & & 100 \\
\hline 20 & Paragorgia johnsoni & & & & & & & & $\mathrm{X}$ & & $\mathrm{X}$ & & & & $1110-1130$ \\
\hline 21 & Paramuricea sp. 1 & & & & & & & & $\mathrm{X}$ & & $\mathrm{X}$ & & & & $1110-1130$ \\
\hline 22 & Paramuricea sp. 2 & & & & & & & & & & $\mathrm{X}$ & & & & $1110-1130$ \\
\hline 23 & Placogorgia sp. & & & & & & & & & & & & $\mathrm{X}$ & & 1110 \\
\hline 24 & Primnoella sp. & & $\mathrm{X}$ & & & & & & & & & & & & 579 \\
\hline 25 & Radicipes sp. & & & $\mathrm{X}$ & & & & & & & & & & & 618 \\
\hline 26 & Renilla muelleri & $\mathrm{X}$ & & & & & & & & & & & & & 60 \\
\hline 27 & Renilla reniformes & $\mathrm{X}$ & & & & & & & & & & & & & 60 \\
\hline 28 & Telestula sp. & & & & & & & & & & $\mathrm{X}$ & & & & 1110 \\
\hline 29 & Thesea bicolor & & $\mathrm{X}$ & & & & & & & & & & & & $60-180$ \\
\hline 30 & Thesea sp. $^{\mathrm{b}}$ & $\mathrm{X}$ & & & & & & & & & & & & & 60 \\
\hline 31 & Trachytella sp. & & & & & & & & $\mathrm{X}$ & & & & & & 1127 \\
\hline 32 & $\begin{array}{l}\text { Umbellula thomsonii } \\
\text { Scleractinia }\end{array}$ & & & & & $\mathrm{X}$ & & & & & $\mathrm{X}$ & $\mathrm{X}$ & & & $1110-1600$ \\
\hline A & Caryophyllia ambrosia & & & & & $\mathrm{X}$ & $\mathrm{X}$ & & $\mathrm{X}$ & & $\mathrm{X}$ & $\mathrm{X}$ & $\mathrm{X}$ & & \\
\hline B & Deltocyathus italicus & & & & & $\mathrm{X}$ & & $\mathrm{X}$ & & $\mathrm{X}$ & $\mathrm{X}$ & $\mathrm{X}$ & $\mathrm{X}$ & $\mathrm{X}$ & \\
\hline $\mathrm{C}$ & Deltocyathus sp. & & & & & $\mathrm{X}$ & $\mathrm{X}$ & $\mathrm{X}$ & & $\mathrm{X}$ & $\mathrm{X}$ & $\mathrm{X}$ & $\mathrm{X}$ & $\mathrm{X}$ & \\
\hline $\mathrm{D}$ & Desmophyllum cristagalli & & & & & & & & $\mathrm{X}$ & & $\mathrm{X}$ & & & & \\
\hline E & Desmophyllum dianthus & & & & & & & & $\mathrm{X}$ & & & & & & \\
\hline $\mathrm{F}$ & Enallopsammia sp. & & & & & & & & $\mathrm{X}$ & & & $\mathrm{X}$ & & & \\
\hline $\mathrm{G}$ & Enallopsammia rostrata & & & & & & $\mathrm{X}$ & & & & & & & & \\
\hline $\mathrm{H}$ & Lophelia pertusa & & & & & & & & $\mathrm{X}$ & & & & & & \\
\hline I & Solenosmilia variabilis & & & & & & $\mathrm{X}$ & & $\mathrm{X}$ & & $\mathrm{X}$ & & & & \\
\hline $\mathrm{J}$ & Stephanocyathus diadema & & & & & & & & & & & & & $\mathrm{X}$ & \\
\hline $\mathrm{L}$ & Stephanocyathus sp. & & & & & & & $\mathrm{X}$ & & $\mathrm{X}$ & & $\mathrm{X}$ & & & \\
\hline
\end{tabular}

Group B (3L, 1L, 4L; $78 \%$ average similarity) is characterized by Anthoptilum murrayi (79\%) and Umbellula thomsonii $(21 \%)$. The average dissimilarity between the 2 groups is $51 \%$, with Anthomasthus grandiflorus contributing $49 \%$. Also note that all lower slope areas plus middle slope area $1 \mathrm{M}$ form a cluster strongly distinct from all other middle slope areas. Area $1 \mathrm{M}$ is much further south than any other middle slope area and is geographically much closer to lower slope area 1L. Due to differences in slope morphology, Groups A and B present some depth overlap (Table 1).
Species (R-mode) cluster analysis for Octocorallia in the Campos Basin demonstrates distinct faunas from the shelf and upper slope species in comparison with those of the middle and lower slopes (Figs. 4 \& 5). A total of 32 species of octocoral occurring in the basin are split evenly between the shelf/upper slope and the middle/lower slope areas. Most ( $81 \%)$ species present in the shallower zone (60 to $775 \mathrm{~m}$, Table 1) occur in a single area (Table 2) and at least half of the species in shelf and central upper slope occur only once. Thus it is not possible to further evaluate the fauna from the shelf and upper slope. 

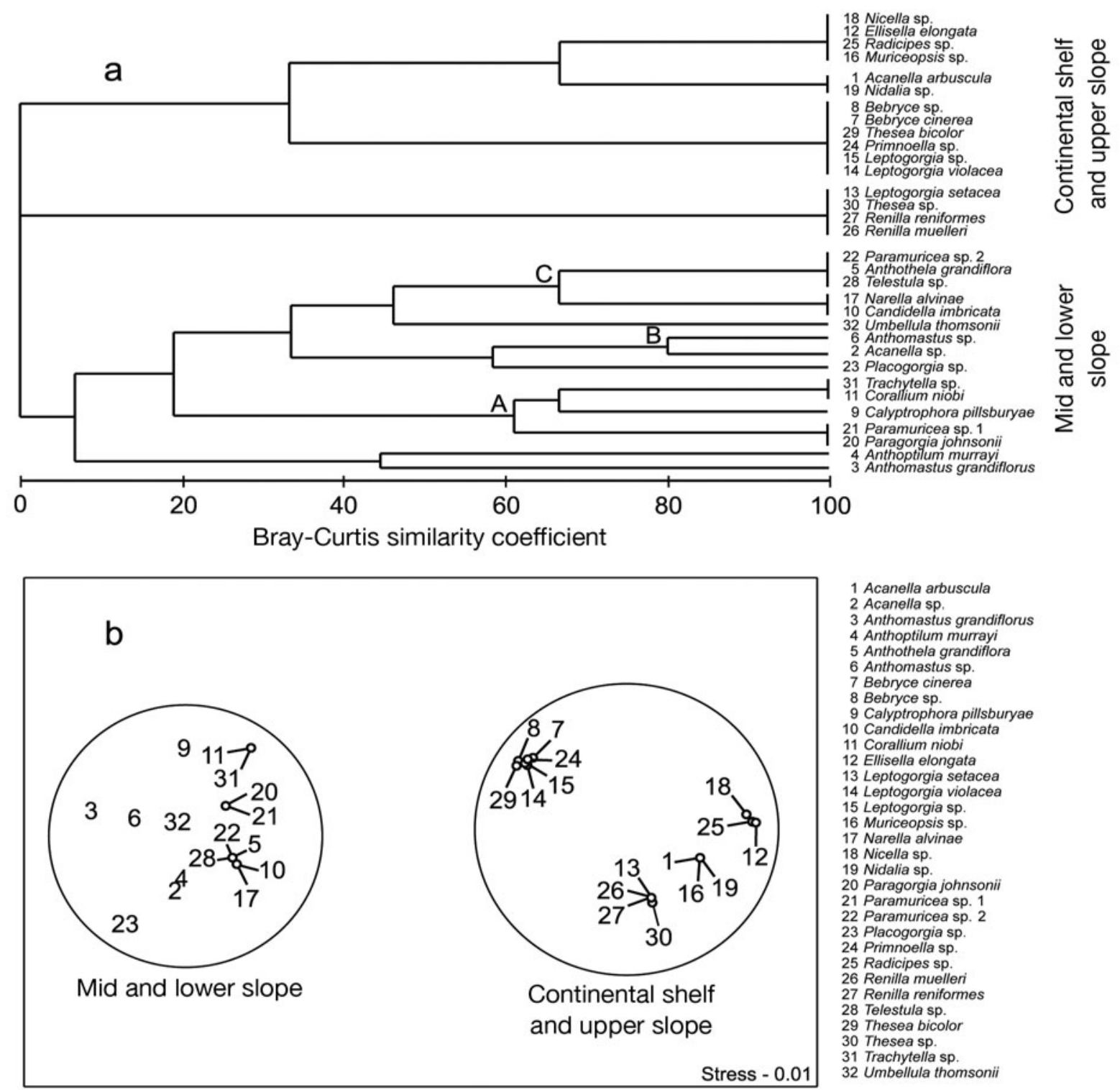

Fig. 3. (a) Cluster analysis dendrogram and (b) MDS ordination of Octocorallia co-occurrence in the Campos Basin. Letters in (a) indicate recognized clusters in mid and lower slope areas. Numbers in (a) and (b) refer to species list to the right

By contrast, only about $38 \%$ of deeper-water species appear only once. A $60 \%$ similarity was adopted for the R-mode cluster analysis (Fig. 3), resulting in 3 groups: (1) Group A: Paragorgia johnsoni, Paramuricea sp. 1, Calyptrophora pillsburyae, Corallium niobe and Trachythella sp. (62\% similarity); (2) Group B: Acanella sp. and Anthomasthus sp. (80\%); and (3) Group C: Candidella imbricata, Narella alvinae, Telestula sp., Anthothela grandiflora and Paramuricea sp. 2 (68\%).

A cluster analysis considering both Octocorallia and Scleractinia evaluated the coral community from the middle and lower slopes (Table 2). Northern middle slope areas ( $4 \mathrm{M}$ and $5 \mathrm{M}$, where the slope trends N-S) have similarities above $40 \%$, whereas for the remaining middle slope areas (where the slope trends $\mathrm{E}-\mathrm{W}$ ), similarities are below $40 \%$. The cluster of areas from the lower slope has a similarity of about $60 \%$ (Fig. 4). MDS results (Fig. 4) also indicate closer proximity among lower slope areas (Group D), with only 2 areas from the middle slope being closer (Group E). Based on these results, a $40 \%$ similarity was used to delineate clusters.

The average similarity for Group D was $65 \%$, with Deltocyathus italicus, Deltocyathus sp. and Anthoptilum murrayi contributing $86 \%$. The average similarity for Group E was $48 \%$, explained by the contribution of about $20 \%$ from the following species: Caryophyllia ambrosia caribbeana, D. italicus, Deltocyathus sp., Acanella sp. and Anthomastus sp. Area 1M and Group D 

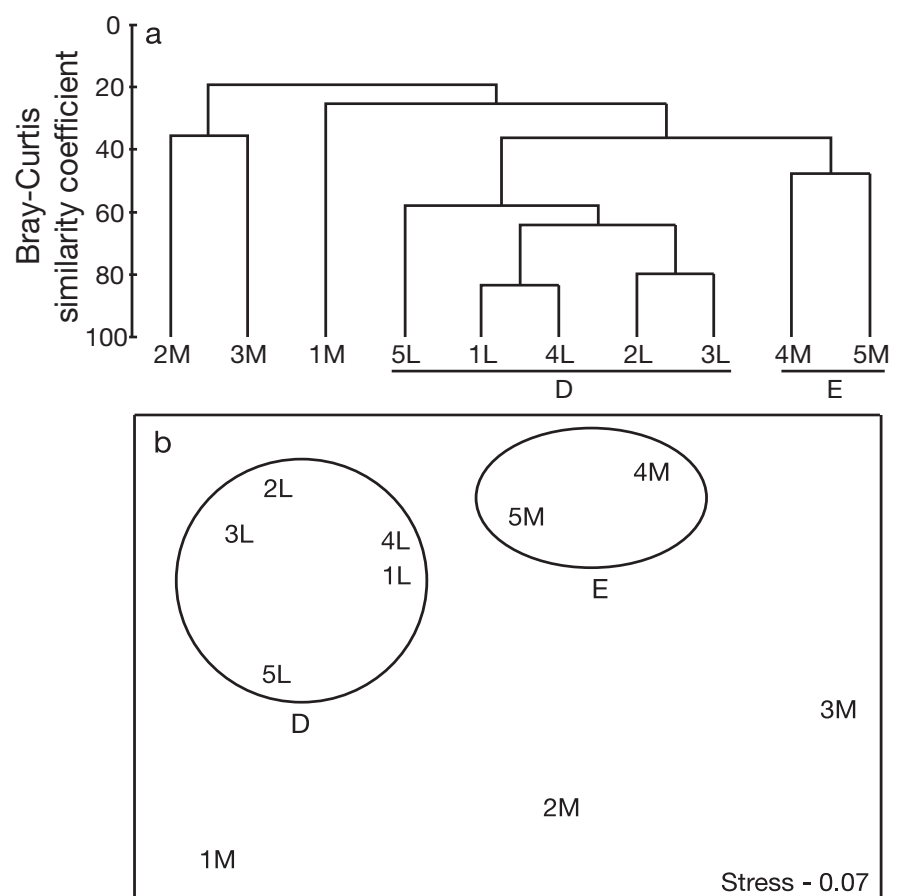

Fig. 4. (a) Cluster analysis dendrogram and (b) MDS ordination of sites in the middle and lower slope areas (see Fig. 1 for area location and subdivision, Table 1 for area codes), based on occurrence of Octocorallia and Scleractinia. Letters in (a) indicate recognized clusters in mid and lower slope areas, which are also shown in (b)

are $71 \%$ dissimilar, with $~ 50 \%$ due to Acanella sp. in $1 \mathrm{M}$, and D. italicus and Deltocyathus sp. in Group D.

Dissimilarity between Group D and Area $2 \mathrm{M}$ is $72 \%$, largely due (61\%) to Deltocyathus italicus and Anthoptilum murrayi in Group D, and Enallopsammia rostrata, Solenosmilia variabilis and Calyptrophora pillsburyae in 2M. Group D and Area 3M have a dissimilarity of $93 \%$, while Groups D and E have a dissimilarity of $63 \%$, with Acanella sp., Anthomastus sp. and Anthoptilum murrayi contributing $33 \%$. Comparing Group E to the rest of the middle slope, average dissimilarity was $83 \%$ relative to Area $1 \mathrm{M}, 69 \%$ to Area $2 \mathrm{M}$ and $75 \%$ to Area $3 \mathrm{M}$.

Among isolated areas, $2 \mathrm{M}$ and $3 \mathrm{M}$ present the lowest dissimilarity at $65 \%$, explained by Deltocyathus sp., Enallopsammia rostrata and Anthomastus grandiflorus in Area 2M, and Trachytella sp., Desmophyllum cristagalli, Desmophyllum dianthus, Enallopsammia sp., Lophelia pertusa, Corallium niobe and Paragorgia johnsoni in Area 3M, each contributing $9 \%$ to the difference. Dissimilarity between Areas 1M and 2M averages $78 \%$. The only completely dissimilar areas are $1 \mathrm{M}$ and $3 \mathrm{M}(100 \%)$.

A total of 27 species was considered for the co-occurrence analysis in the middle and lower slope: 16 species of Octocorallia and 11 of Scleractinia. Cluster analysis dendrogram and MDS (Fig. 5) interpretation suggest a $60 \%$ limit for cluster definition, resulting in 5 distinct groups (F to J).

The larger of these groups, F, consists of 10 species, with a $60 \%$ similarity, and could be subdivided into 3 smaller subgroups: (1) with a $68 \%$ similarity index, is comprised of Enallopsammia sp., Corallium niobe, Trachytella sp., Desmophyllum dianthus and Lophelia pertusa; (2) consists of Desmophyllum cristagalli, Paragorgia johnsoni and Paramuricea sp. 1, with a similarity index of $65 \%$; (3) subgroup has the highest similarity, $80 \%$, and is comprised of Calyptrophora pillsburyae and Solenosmilia variabilis.

Group G, comprised of Umbellula thomsonii and Caryophyllia ambrosia caribbeana, has a similarity index of approximately $68 \%$, while Group $\mathrm{H}$ has an index of $60 \%$ and is formed by Deltocyathus italicus, Deltocyathus sp. and Anthoptilum murrayi. The final 2 groups include only octocorals - Group I (Candidella imbricata, Narella alvinae, Telestula sp., Anthothella grandiflora and Paramuricea sp. 2) and Group J (Acanella sp. and Anthomastus sp.) - and have similarity indices of 68 and $80 \%$, respectively.

\section{DISCUSSION}

\section{Habitat association}

Octocorals exhibit a wide range of adaptations, often associated with specific environments. The order Pennatulacea, for instance, is associated with unconsolidated sediments (Bayer 1961) and, exclusively among octocorals, species possess a peduncle for anchoring in mud and sand. Most other octocorals have a basal disk for fixation in rocky or other rigid substrates, although some bamboo corals (Isididae) developed basal, rootlike processes that anchor the colony in sediment substrates (Bayer 1961). Both types of bases occur among Campos Basin octocoral species, indicating the presence of both hard and soft substrates.

Co-occurrences of octocorals in the middle and lower slopes indicate 3 highly similar clusters (>60\%). A group formed by Anthomasthus sp. and Acanella sp., both of which possess root-like bases, present the largest inner similarity $(80 \%)$, suggesting a softbottom environment. The 2 other clusters include genera with morphologies associated with hard-substrate. Among these genera, some are indicative of coldwater reef environments, as 4 of them are associated with the presence of lithoherms (Reed 2002): Paragorgia, Corallium, Narella and Paramuricea. Three such genera were present in the same cluster (Fig. 3), another indication of the occurrence of cold-water coral habitats in Campos Basin. 

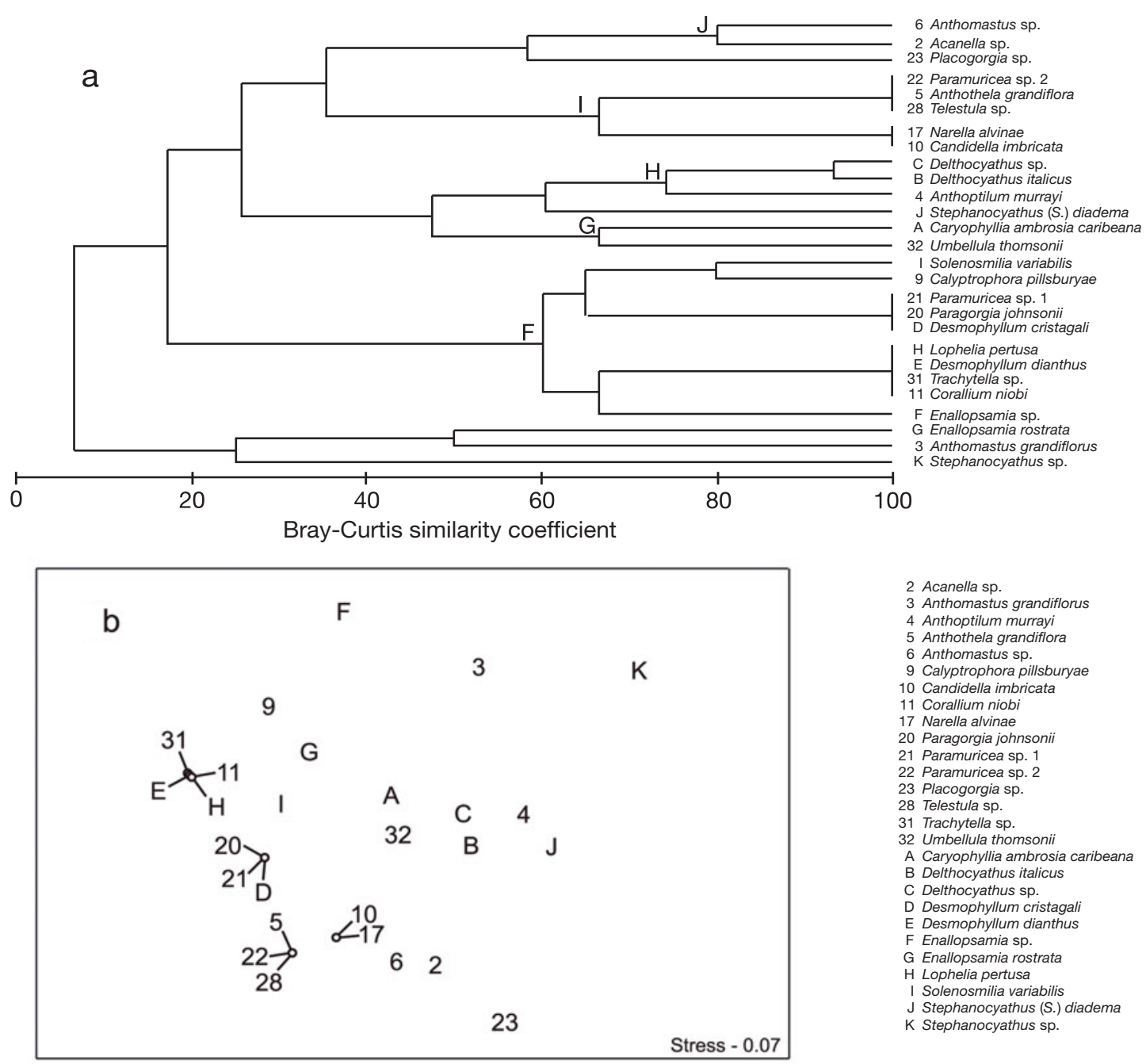

2 Acanella sp.

3 Anthomastus grandiflorus

4 Anthoptilum murrayi

5 Anthothela grandiflor

9 Calyptrophora pillsburyae

10 Candidella imbricata

11 Corallium niobi

17 Narella alvinae

20 Paragorgia johnsoni

21 Paramuricea sp. 1

22 Paramuricea sp.

23 Placogorgia sp.

28 Telestula sp.

31 Trachytella sp.

A Caryophyllia ambrosia caribeana

A Delthocyathus italicus

C Delthocyathus sp.

D Desmophyllum cristagali

E Desmophyllum dian

G Enallopsamia sp.

G Enallopsamia rostrata

H Lophelia pertusa
I Solenosmilia variabilis

J Stephanocyathus (S.) diadema

$\mathrm{K}$ Stephanocyathus $\mathrm{sp}$.

Stress -0.07

Fig. 5. (a) Cluster analysis dendrogram and (b) MDS ordination of Octocorallia and Scleractinia co-occurrence in the Campos Basin. Letters near cluster nodes in (a) indicate recognized clusters. Numbers and letters in (a) and (b) refer to species list to the right

Distribution of octocoral and stony coral species (Fig. 4) yield areal groupings similar to those of octocorals only (Fig. 2). Species that contributed most to the lower slope cluster are: Deltocyathus italicus, Deltocyathus sp. and Stephanocyathus diadema, which are solitary species with unattached bases, and Anthoptilum murrayi, which has a peduncle. Lower slope species contributing to cluster formation indicate this uniformity to be predominantly associated with nonconsolidated substrates, such as mud and sand. The middle slope has low similarity among areas and presents more geomorphological variation than the lower slope (Fig. 1). The middle slope shelters higher habitat diversity, including reef environments, as well as nonconsolidated bottom habitats.

Reed (2002) compared the composition of communities in different cold-water reefs off Florida and concluded that geomorphological structure and high speed currents were similar in these reefs. The difference in species composition was correlated to reefforming species and local sedimentary setting. Mortensen \& Buhl-Mortensen (2004) stated that strong currents may accelerate in areas with topographic irregularities, which can locally increase the supply of food and larvae. Limiting controlling factors (e.g. substrate, salinity and temperature) rule the occurrence and distribution of species over large spatial scales, while other factors (e.g. food supply) regulate the distribution over small scales (Mortensen \& Buhl-Mortensen 2004). When all environmental conditions are favorable, corals may produce extensive structures that trap sediments and provide shelter for many other benthic organisms, such as sponges (Rogers 1999). The middle slope in Campos Basin is under the influence of strong currents (Viana et al. 1998). Several canyons cut the area and influence water flow (Fig. 1), creating an 
area of high diversity, especially for sponges (Muricy et al. 2006) and corals (Castro et al. 2006).

Co-occurrences of octocorals and stony corals (Fig. 5) resulted in 5 clusters with $>60 \%$ similarity, which indicates different habitats. The most diverse cluster (Group F), was mostly composed of species indicative of cold-water coral habitats, e.g. the stony corals Lophelia pertusa and Enallopsammia spp., and the octocorals Corallium niobe, Paramuricea sp. and Paragorgia johnsoni. Other clusters (Groups G and H) were formed by species indicative of environments dominated by mud and sand, including Caryophyllia ambrosia caribbeana, Umbellula thomsonii, Dethocyathus italicus, Dethocyathus sp. and Anthoptilum murrayi. The remaining clusters (Groups I and J) were composed exclusively of octocorals, especially arborescent forms, which may be associated with the physical structure of cold-water reefs. Messing et al. (1990) observed zonation on lithoherms in 500 to $800 \mathrm{~m}$ depths, where gorgonians and crinoids occurred mostly along the flanks and downcurrent end of the ridges. Among the indicative organisms they reported, the primnoid Candidella imbricata was also found in one of the clusters exclusively with octocorals. Therefore, some samples from the OceanProf cruises were possibly taken from cold-water coral habitat margins.

\section{Areal distribution}

Several factors contribute to faunal composition of deep coral environments. Messing et al. (1990), Viana et al. (1998), Reed (2002), Leverette (2004) and Mortensen \& Buhl-Mortensen (2004) suggest that factors associated with bathymetry (e.g. temperature) or water masses may control distributions of shelf and slope corals. Water masses have diverse environmental characteristics, such as speed of flow, temperature, salinity, nutrients and $\mathrm{pH}$. They can influence spatial and temporal patterns of food (plankton and organic debris, such as dead organisms and fecal pellets) in deep-sea benthic communities (Clark et al. 2006). Viana et al. (1998) reported cold-water corals in the Campos Basin between the 570 and $850 \mathrm{~m}$ isobaths. At these depths, the superior portion of AIW predominates, causing the oxidation of the bottom and the transport of azooxanthellate coral larva, which eventually settle. In addition to the water mass, an adequate substrate is needed for fixation (Messing et al. 1990).

In the present study, different communities were associated with 3 bathymetric and water mass zones. The first consists of the continental shelf and upper slope, with depths ranging from 52 to $760 \mathrm{~m}$, under the influence of TW and SACW (and upper AIW), and includes 16 species. Sampling in this zone was very limited and did not allow us to distinguish faunas associated with TW from those of the SACW. The second zone corresponds to the middle slope (1000 to $1200 \mathrm{~m}$ ) under the influence of AIW, while the third zone (lower slope, 1200 to $1605 \mathrm{~m}$ ) is under the influence of NADW.

Five species occur on the slope alone, although over a $400 \mathrm{~m}$ depth range: Anthomastus grandiflorus, Anthoptilum murrayi, Candidella imbricata, Narella alvinae and Umbellula thomsonii. These generalist species occur both under the influence of AIW and NADW, in the middle and lower slopes, respectively. Three of the 5 species, Anthomastus grandiflorus, Anthoptilum murrayi and $U$. thomsonii were recorded by Castro et al. (2006) between 804 and 2219 m depths elsewhere in east and southeast Brazil, further associating these species with areas under the influence of AIW and NADW. The remaining 11 species found in the shelf and upper slope occured only in areas under the influence of AIW, while no species occurred exclusively in areas under the influence of NADW. Bathymetry seems to be a factor that directly or indirectly influences conditions necessary for survival and development of certain corals.

The distribution of species on the middle slope under AIW influence is more heterogeneous than on the lower slope under NADW influence. Data presented here indicate a region of cold-water corals on the middle slope under the influence of AIW, complementing Viana et al. (1998) and Castro et al. (2006), who reported coral environments in areas under the influence of AIW, although in shallower waters. Sumida et al. (2004) indicated that cold-water coral communities in Santos Basin, to the south of the area we studied, are also under the influence of AIW.

AIW and NADW, the water masses present in the slope of the Campos Basin, have circumglobal circulation patterns. As such, they are the same water masses that influence the Tasmanian seamounts (Commonwealth of Australia 2002). The depths bathed by each water mass, however, have regional variations. Rintoul et al. (1997) and Rintoul \& Bullister (1999) mention that AIW flows between 500 to 1500 m depth in South Tasmania, while NADW flows deeper than $1500 \mathrm{~m}$.

As the Commonwealth of Australia (2002) sampled exclusively depths shallower than 1000 m, one can conclude these samples to have been collected under AIW influence. Of the 20 genera found by the Commonwealth of Australia (2002) in Tasmania, 8 are also found in the Campos Basin: Anthomastus, Anthothela, Corallium, Chrysogorgia, Paragorgia, Paramuricea, Calyptrophora and Narella. Most occur in AIW-influenced areas, except for Anthomastus and Narella, which occur in the Campos Basin at both AIW and NADW depths (see Table 2). Note that in Tasmania, NADW-influenced depths were not sampled. 
AIW-influenced areas harbored a greater number of species when compared to NADW-influenced areas within the Campos Basin, although it must be noted that NADW extends to depths of $3500 \mathrm{~m}$, well below the maximum sampled depths (1600 $\mathrm{m})$. Among the fauna occurring only in the AIW-influenced areas (depths above $1200 \mathrm{~m}$ ), the presence of species usually found in cold-water coral habitats elsewhere in the world (Messing et al. 1990, Heifetz 2002, Reed 2002) is noteworthy.

Several authors (Reyes-Bonilla \& Cruz-Piñón 2002, Reed 2002, Leverette 2004) relate deep coral habitats to local oceanographic patterns to predict conditions that might favor the development of such communities. The physical-chemical properties of AIW (2 to $6^{\circ} \mathrm{C}$ temperature range, high dissolved $\mathrm{O}_{2}, 34.2 \mathrm{ppm}$ minimum salinity; Viana et al. 1998) are probably the most adequate for the development and survival of the coral communities not only in the Campos Basin, but also in other cold-water habitats elsewhere in the world.

Acknowledgements. The projects Assessment of the Sustainable Yield of the Living Resources in the Exclusive Economic Zone (REVIZEE) and the Campos Basin Deep-Sea Environmental Project donated the specimens for this study. We thank A. P. Falcão (Petrobras) for suggestions along the course of the study. D.O.P., C.B.C. and J.C.S.S. thank the Conselho Nacional de Desenvolvimento Científico e Tecnológico Brazil for research fellowships. R.C.M.A. thanks Petrobras for a Master's fellowship. Thanks to Petrobras and the United Nations Environment Program for travel grants to D.O.P., C.B.C. and R.C.M.A. to attend the 4th International Symposium on Deep-Sea Corals.

\section{LITERATURE CITED}

Arantes RCM, Medeiros MS (2006) Primeiro registro de Anthothela grandiflora (Sars, 1856) (Cnidaria: Octocorallia) no Brasil. Bol Mus Nac Zool (Rio J) 64:11-17

Bayer FM (1961) The shallow water Octocorallia of the West Indian region. Martinus Nijhoff, The Hague

Bayer FM (1981) Key to the genera of Octocorallia exclusive of Pennatulacea (Coelenterata: Anthozoa), with diagnosis of new taxa. Proc Biol Soc Wash 94:902-947

Cairns SD (1979) The deep-water Scleractinia of the Caribbean Sea and adjacent waters. Stud Fauna Curaçao $57: 1-341$

Cairns SD (2000) A revision of the shallow-water azooxanthellate Scleractinia of the western Atlantic. Stud Nat Hist Carib Reg 75:1-321

Castro CB, Medeiros MS (2001) Brazilian Pennatulacea (Cnidaria: Octocorallia). Bull Biol Soc Wash 10:140-159

Castro CB, Pires DO, Medeiros MS, Loiola LL, Arantes RCM, Thiago CM, Berman E (2006) Cnidaria. In: Lavrado HP, Ignacio BL (eds) Biodiversidade bêntica da costa central da Zona Econômica Exclusiva Brasileira. Museu Nacional, Rio de Janeiro, Livros 14, p 147-192

Clark MR, Tittensor D, Rogers AD, Brewin P and others (2006) Seamounts, deep-sea corals and fisheries: vulnerability of deep-sea corals to fishing on seamounts beyond areas of national jurisdiction. UNEP-WCMC, Cambridge
Clarke KR, Warwick RM (1994) Change in marine communities: an approach to statistical analysis and interpretation. Plymouth Marine Laboratory, Natural Environment Research Council, Plymouth

Commonwealth of Australia (2002) Tasmanian Seamounts Marine Reserve Management Plan. Environment Australia, Canberra

Heifetz J (2002) Coral in Alaska: distribution, abundance, and species associations. Hydrobiologia 471:19-28

Leverette TL (2004) Predicting suitable habitat for deep water corals in the Pacific and Atlantic continental margins of North America. MS thesis, Dalhousie University, Halifax

Levin LA, Gooday AJ (2003) The Atlantic ocean. In: Tyler PA (ed) Ecosystems of the world 28. Ecosystems of the deep oceans. Elsevier, Amsterdam, p 111-178

Medeiros MS, Castro CB (1999) Paramuriceidae e Plexauridae (Cnidaria, Octocorallia) do Brasil: batimetria e distribuição geográfica. Bol Mus Nac Zool (Rio J) 398:1-20

Messing CG, Neumann CA, Lang JC (1990) Biozonation of deep-water lithoherms and associated hardgrounds in the northeastern Straits of Florida. Palaios 5:15-33

Mortensen PB, Buhl-Mortensen L (2004) Distribution of deepwater gorgonian corals in relation to benthic habitat features in the Northeast Channel (Atlantic Canada). Mar Biol 144:1223-1238

Muricy G, Santos CP, Batista D, Lopes DA and others (2006) Porifera. In: Lavrado HP, Ignacio BL (eds) Biodiversidade bêntica da costa central da Zona Econômica Exclusiva Brasileira. Museu Nacional, Rio de Janeiro, Livros 14, p 109-145

Reed JK (2002) Comparison of deep-water coral reefs and lithoherms off southeastern USA. Hydrobiologia 471: $57-69$

Reyes-Bonilla H, Cruz-Piñón G (2002) Influence of temperature and nutrients on species richness of deep water corals from the western coast of the Americas. Hydrobiologia 471:35-41

Rintoul SR, Bullister JL (1999) A late winter hydrographic section from Tasmania to Antarctica. Deep-Sea Res I 46: $1417-1454$

> Rintoul SR, Donguy JR, Roemmich DH (1997) Seasonal evaluation of upper ocean thermal structure between Tasmania and Antarctica. Deep-Sea Res I 44:1185-1202

Rogers AD (1999) The biology of Lophelia pertusa (Linnaeus 1758) and other deep-water reef-forming corals and impacts from human activities. Int Rev Hydrobiol 84: 315-406

> Sumida PYG, Yoshinaga MY, Madureira MASP, Hovland M (2004) Seabed pockmarks associated with deepwater corals off SE Brazilian continental slope, Santos Basin. Mar Geol 207:159-167

Tixier-Durivault A (1970) Octocoralliaires. Campagne de la 'Calypso' au large des cotes atlantiques de l'Amerique du Sud (1961-1962). Ann Inst Oceanogr 47:145-169

Viana AR, Faugères JC, Kowsmann RO, Lima JAM, Caddah LFG, Rizzo JG (1998) Hydrology, morphology and sedimentology of the Campos continental margin, offshore Brazil. Sediment Geol 115:133-157

Watling L, Auster PJ (2005) Distribution of deep-water Alcyonacea of the northeast coast of the United States. In: Freiwald A, Roberts JM (eds) Cold-water corals and ecosystems. Springer-Verlag, Berlin, p 279-296

Williams GC (1995) Living genera of sea pens (Coelenterata: Octocorallia: Pennatulacea): illustrated key and synopses. Zool J Linn Soc 113:93-140 